\title{
Green Manuring for Increasing Nitrogen use Efficiency and Growth Performance of Wheat
}

\author{
Ghulam Muhammad ${ }^{1}$, Shahinshah Khan ${ }^{2}$, Mustajab A Khan², Javed Anjum ${ }^{1}$, Nazeer Ahmed Alizai ${ }^{1}$, Kamran Anjum ${ }^{1}$, \\ Hidayatullah Kakar $^{1 *}$, Tariq Ziad ${ }^{1}$ \\ ${ }^{1}$ Agriculture Research Institute, Quetta, Balochistan, Pakistan \\ ${ }^{2}$ Balochistan Agriculture College Quetta, Pakistan \\ *Corresponding Author: Hidayatullah Kakar \\ kaintkk@gmail.com
}

Article Received 07-12-2021, Article Revised 02-01-2022, Article Accepted 09-01-2022

\begin{abstract}
In the absence of organic matter, the soil is an inert matter and cannot sustain productivity. The soil fertility scenario of Pakistan depicts low organic matter status and low nitrogen contents and has low use efficiency. This study was initiated during 2017-18 to enhance soil nitrogen contents and organic matter through green manuring and augmentation of $\mathrm{N}$ use efficiency under agro-ecological condition of Quetta. This experiment consists of five treatments $\left(\mathrm{T}_{1}=\right.$ Green manuring $(\mathrm{GM}) ; \mathrm{T}_{2}=\mathrm{GM}+25 \%$ recommended $\mathrm{N}\left(30 \mathrm{~kg} \mathrm{~N} \mathrm{ha}^{-1}\right) ; \mathrm{T}_{3}=\mathrm{GM}+50 \% \mathrm{~N}\left(60 \mathrm{~kg} \mathrm{~N} \mathrm{ha}^{-1}\right) ; \mathrm{T}_{4}=$ $\mathrm{GM}+75 \% \mathrm{~N}\left(90 \mathrm{~kg} \mathrm{~N} \mathrm{ha}^{-1}\right) ; \mathrm{T}_{5}=\mathrm{GM}+100 \% \mathrm{~N}\left(120 \mathrm{~kg} \mathrm{~N} \mathrm{ha}^{-1}\right)$ and three replications based on randomized complete block design (RCBD). The results revealed that all the study parameters except plant height and chlorophyll contents were improved when 75 and $100 \%$ recommended $\mathrm{N}$ were applied to wheat crops after green manuring. Green manuring helped in enhancing soil $\mathrm{N}$ level when $75 \%$ recommended $\mathrm{N}$ was applied because both 75 and $100 \% \mathrm{~N}$ expressed statistically at par differences for wheat traits and yield. In addition, green manuring increased NUE by 68.9, 147.0, 126.2, and 100.8\% across different $\mathrm{N}$ percentages $(25,50,75$ and $100 \%)$. However, without the addition of nitrogen fertilizer, only green manuring could not meet the $\mathrm{N}$ requirement of wheat crops. Consequently, it is inferred that green manuring helped in enhancing soil organic matter and total nitrogen when $\mathrm{N}$ fertilizer was applied to the wheat crop. It is suggested that various green manure crops can be evaluated to augment SOM and TN for the succeeding crop.
\end{abstract}

Keywords: Green manuring, nutrients availability, nutrient use efficiency, wheat, yield

\section{Introduction}

Soil organic matter plays a significant role in sustainable agriculture production. Green manuring as an organic amendment is practiced in various cropping systems by farmers across the world (Bai et al., 2017). Different crops are grown for the purpose of green manuring but the legumes are intended superior over nonlegume in terms of augmentation of more organic matter and soil nitrogen level (Carlsson and Danell, 2003). In addition, green manuring helps in moisture conservation, particularly in water scare farming system (Hasan et al., 2014). The superiority of leguminous crops included alfalfa, beans, clovers, lupines and vetchs as green manure is due to its ability of nitrogen fixation through symbiosis leading to buildup soil nitrogen level that can be utilized by the succeeding crops (Ramos et al., 2001). The practice of green manuring results in reduction of inputs such as in applying nitrogenous fertilizers and accelerates the availability of soil internal resources for many crops grown successfully on manured soil (Bohlool et al., 2004). For the best performance of green manuring, those crops must be selected fulfilling the criteria of fast and vigorous vegetative growth early with deep roots, have non-fibrous tissues, required less water for growth, possess nutrients for supplying to soil and have the ability to decompose rapidly after incorporating in the soil (Singh et al., 2013).

Soil properties are influenced under the practice of green manuring. A group of researchers have reported that green manuring affect soil physical properties to great extent such as decreased soil bulk density, increased soil porosity, improved soil structure in terms of water stable aggregates and soil organic matter. They further noted enhancement in soil total and available nitrogen (Luo et al., 2020). The accumulation of dry matter of crop is directly influenced by the nitrogen uptake where nitrogen management practices are carried out in terms of increasing soil organic matter (Kumar et al., 2014). A group of researchers evidenced that the crop grain yield and biological yield was significantly correlated with nitrogen uptake (Deng et al., 2014). However, some researchers reported that the correlation between dry matter and $\mathrm{N}$ uptake in rice crop varied with respect to growth stages (Zhou et al., 2016). According to the findings of another group of researchers that when the growth of rice crop reached to tillering and panicle initiation stages the accumulation of nitrogen and dry matter augmented correspondingly (Liu et al., 2015; Ma et al., 2015). It is known scientifically that the application of $\mathrm{N}$ fertilizer in high rates results in non-productive tillers because of more vegetative growth or more tillering which has already been reported in China where farmers use high 
rates of fertilizers with intention of getting more dry matter and grain yield (Cao et al., 2013; Zhang et al., 2017).

The residual effect of green manuring remains in soil for years ( $>1$ year). In a study conducted by Yadav et al. (2003) reported that the application of $\mathrm{N}$ fertilizer was reduced in succeeding crop when cowpea crop was used as green manuring for better $\mathrm{N}$ availability and improved nitrogen use efficiency of the applied $\mathrm{N}$ fertilizer. The use of sesbania and cowpea as green manure crop improved soil physical and chemical properties in terms of increased soil organic matter, soil nitrogen level and soil health. Such improvements in soil resulted in enhancement of growth and grain yield of the succeeding crop where the applied fertilizer efficiency increased in comparison to sole fertilizer usage without having green manuring (Patra et al., 2000). Similar results were reported by Kumar et al. (2011) that green manuring augmented soil N, P and K concentration by $12-21 \%$, soil organic matter by $12 \%$. Likewise, improvement in soil health and crop growth was recorded by Salahin et al. (2013) after green manuring practice. Belachew and Abera (2011) compared vetch green manuring with fallow on soil properties and noted reduction in soil $\mathrm{pH}$ and improvement in soil organic matter when vetch crop was incorporated after three weeks of growth.

Without the use of chemical fertilizer, the sole practice of green manuring cannot support the crop growth sustainably. To meet the nutrients requirement of high yielding varieties the integrated use of green manuring and synthetic fertilizer is one of the best options along with adoption of other agronomic practices like timely sowing, weeding, irrigation and pest and disease control (Dikemann et al., 1993; Yadav, 2001). A green manuring study conducted by Ghuman and Sur (2006) during six seasons reported increased in grain yield of wheat during four seasons while the other 2 seasons reflected little differences in yield under rice wheat cropping system. In another investigation carried out by Yadav et al. (2003) on cowpea green manuring's influence on wheat as succeeding crop and revealed 19$20 \%$ increase in wheat grain yield over the treatment where no green manuring was practiced. Keeping in view the importance of green manuring the present study was undertaken to increase soil nitrogen contents and organic matter through green manuring that subsequently improved growth, yield and nutrient use efficiency of wheat as a succeeding crop.

\section{Materials and Methods}

A field trial was carried out at the experimental field of ARI (Agriculture Research Institute), Quetta during the year 2017-18. The experiment was based on Randomized Complete Block Design with five treatments which were replicated thrice in plot size of $15 \mathrm{~m}^{2}$. The treatments were designed as $\mathrm{T}_{1}=$ Green manuring $(\mathrm{GM}) ; \mathrm{T}_{2}=\mathrm{GM}+25 \%$ recommended $\mathrm{N}\left(30 \mathrm{~kg} \mathrm{~N} \mathrm{ha}^{-1}\right) ; \mathrm{T}_{3}=\mathrm{GM}+50 \% \mathrm{~N}(60 \mathrm{~kg}$ $\left.\mathrm{N} \mathrm{ha}{ }^{-1}\right) ; \mathrm{T}_{4}=\mathrm{GM}+75 \% \mathrm{~N}\left(90 \mathrm{~kg} \mathrm{~N} \mathrm{ha}^{-1}\right) ;$ and $\mathrm{T}_{5}=$ $\mathrm{GM}+100 \% \mathrm{~N}\left(120 \mathrm{~kg} \mathrm{~N} \mathrm{ha}^{-1}\right)$. The field was divided into sub-plots according to the experimental description. Sesbania aculeata (Linn) was used as a green manure (GM) crop and wheat variety Zardana was sown as a succeeding crop. Sesbania aculeata (Linn) was sown on first August, 2017 by hand drill with row to row distance of $40 \mathrm{~cm}$ using seed rate of $50 \mathrm{~kg} \mathrm{ha}^{-1}$. When the growth of $\mathrm{GM}$ reached to flowering i.e. 60 days after their establishment, then mixed in the soil through rotavator (Sultani et al., 2004). While, wheat was sown on 15th November through single coulter hand drill using seed rate of $125 \mathrm{~kg} \mathrm{ha}^{-1}$. The phosphorus and potassium were applied @ 90 and $50 \mathrm{~kg} \mathrm{ha}^{-1}$ using single super phosphate and sulphate of potash. While, $\mathrm{N}$ was applied per treatments using urea. All $\mathrm{P}, \mathrm{K}$ and $1 / 4 \mathrm{~N}$ were added during sowing time. However, remaining $\mathrm{N}$ per treatments were applied into split doses at the time of $1^{\text {st }}$ and $2^{\text {rd }}$ irrigations. The wheat crop was given 5 irrigations according to critical stages of crop growth.

Soil analysis: The soil of the experimental site was analyzed for physicochemical properties included texture, organic matter, $\mathrm{pH}, \mathrm{EC}$, Macronutrients ( $\mathrm{N}, \mathrm{P}$ and $\mathrm{K}$ concentration). Bouyoucos hydrometer method was used for determination of soil texture (Bouyoucos, 1962), organic matter contents of soil by oxidizing method (Walkley, 1947 and Black 1993). Soil pH and EC (Electrical conductivity) was determined in 1:20 soil to water ratio (McLean, 1982). While, available $\mathrm{P}$ and $\mathrm{K}$ by AB-DTPA extraction method (Soltanpour and Schwab, 1977) and N by Kjeldahl's method (Jones, 1991). Though, after the completion of production cycle of wheat, soil samples were collected from each replicated treatment and analyzed for determination of the properties as for the pre soil samples.

Plant tissue analysis: Flag leaf was collected from 10-30 plants in each plot at milking stage. The samples were then put in the paper envelopes, labeled them with permanent marker and delivered to Soil and Water Testing Laboratory ARI Sariab Quetta the same day and stored them over there at room temperature i.e. $20^{\circ} \mathrm{C}$ for next coming working day. The samples were decontaminated and washed following the method of Sonneveld \& Dijk (1982), oven dried at $80^{\circ} \mathrm{C}$, ground to 20 mesh and stored in plastic bags at $4{ }^{\circ} \mathrm{C}$ in the Laboratory for target analysis. Wheat grains were also analyzed for total nitrogen, phosphorus and potassium contents following the same procedure as adopted for leaf tissue as well.

The prepared leaf and grain samples were processed through wet digestion method as proposed by Wolf (1982). From these samples, $0.5 \mathrm{~g}$ was weighed and taken in Kjeldahl flask, added $5.0 \mathrm{ml} \mathrm{H}_{2} \mathrm{SO}_{4}$, kept overnight and on the next day added few pumice granules and digested on high temperature $\left(380^{\circ} \mathrm{C}\right)$ for one hour. After cooling down $2 \mathrm{ml} \mathrm{H}_{2} \mathrm{O}_{2}$ was added and digested for 10 minutes 
and continued the repeated addition of $\mathrm{H}_{2} \mathrm{O}_{2}$ until the whole sample was digested. The macronutrient such as $\mathrm{N}$, $\mathrm{P}$ and $\mathrm{K}$ contents in the clear digest was carried out following the specific protocol for each nutrient. In the digest, total nitrogen was determined by Kjeldhal method (Jones, 1991), P was detected on spectrophotometer (Jenway 6105, Uv-Vis Spectrophotometer, U.K.) following the method described by Cottentie (1980) while, K was determined directly by Flame Photometer (Jenway-PFP7, UK) (Knudsen et al., 1982).

Agronomic traits: The data regarding plant height, Spad chlorophyll contents, tillers $\mathrm{m}^{-2}$, spike length, spikelet spike ${ }^{1}$, seed index, harvest index, biological yield, and grain yield were collected. The measurement of these traits was performed: plant height in centimeter was measured from the surface of the ground to the tip of flag leaf with the help of measuring tape; Spad chlorophyll meter was used for measuring chlorophyll contents; at the time of harvest tillers $\mathrm{m}^{-2}$ were counted per treatment; spike length was noted with measuring tape; for spikelet spike ${ }^{-1}, 25$ spikes per treatment were selected randomly and counted spikelet spike ${ }^{-1}$ and converted into average; sun-dried seeds of each treatment were taken and weighed 1000 seed as seed index; both biological and grain yield of $15 \mathrm{~m}^{2}$ plot were obtained at the time of harvest and converted it into $\mathrm{tha}^{-1}$ and harvest index was calculated as a ratio of grain and biological yield.

\section{Nutrient uptake $\left(\mathrm{kg} \mathrm{ha}^{-1}\right)$}

N-uptake: Nitrogen uptake was calculated through TDM x $\mathrm{N}$ concentration in plant/(100).

P-uptake: Phosphorus uptake was observed through TDM x P concentration in plant /(100).

K-uptake: Potassium uptake was observed through TDM x $\mathrm{K}$ concentration in plant /(100).

Statistical analysis: One way analysis of variance was carried out through Statistix 8.1 computer software. The
LSD value for mean comparison was calculated only if the general treatment $\mathrm{F}$ test was significant at probability of $\leq 0.05$ (Gomez and Gomez, 1984).

\section{Result and Discussion}

Before the plantation of green manure crop, a composite soil sample was collected from the site and its physicochemical properties were determined as shown in Table 1. Texturally, the soil was sandy clay loam with particle size distribution of $47.4 \%$ sand, $31.6 \%$ silt and $21.0 \%$ clay indicating that the soil is medium in texture. The chemical properties of the soil revealed alkaline nature having $\mathrm{pH} 8.13$ and non-saline with electrical conductivity of $1.27 \mathrm{dSm}^{-1}$. More importantly, the soil carbon status in terms of soil organic matter manifested that the experimental site was low in SOM $(0.54 \%)$. In case of the plant essential macronutrients particularly total nitrogen, phosphorus and potassium, the soil of the experimental area was found low in total nitrogen contents $(0.028 \%)$ and AB-DTPA extractable phosphorus $(2.17 \mathrm{mg}$ $\left.\mathrm{kg}^{-1}\right)$. However, plant available potassium content (71.24 $\mathrm{mg} \mathrm{kg}^{-1}$ ) was recorded in medium level. This is because the soil of Pakistan including Balochistan contain potassium bearing minerals which become available to plants intermittently during cultivation and ploughing. The availability of other nutrients particularly phosphorus is one of the limiting factors in agriculture production. In such calcareous and alkaline soil, the efficiency of applied fertilizers is also low. In addition to that SOM play a very significant role in soil health and productivity because in the absence of SOM, soil is an inert material that can't support plant growth (Bedini et al., 2013; Tian et al., 2016).

Table 1. Soil properties of the experimental site

\begin{tabular}{|c|c|c|}
\hline Soil parameters & Unit & Result \\
\hline Sand & $\%$ & 47.4 \\
\hline Silt & $\%$ & 31.6 \\
\hline Clay & $\%$ & 21.0 \\
\hline Textural class & & Sandy clay loam \\
\hline Soil organic matter & $\%$ & 0.54 \\
\hline $\mathrm{pH}$ & & 8.13 \\
\hline $\mathrm{EC}_{1: 2}$ & $\mathrm{dSm}^{-1}$ & 1.27 \\
\hline Total nitrogen & $\%$ & 0.028 \\
\hline AB-DTPA extractable phosphorus & $\mathrm{mg} \mathrm{kg}^{-1}$ & 2.17 \\
\hline AB-DTPA extractable Potassium & $\mathrm{mg} \mathrm{kg}^{-1}$ & 71.24 \\
\hline
\end{tabular}

Analysis of variance presenting F-value and coefficient of variance of the deliberate parameters of wheat crop and post soil organic matter and total nitrogen contents as affected by green manuring integrated with 25 , 50, 75 and $100 \%$ recommended nitrogen are given in Table 2. Except plant height and chlorophyll contents, all the studied parameters showed highly significant differences across the treatments. The statistical analysis revealed greater number of tillers hill-1 ${ }^{-1}(10.67)$ and spike length $(9.20 \mathrm{~cm})$ in $\mathrm{T} 4(\mathrm{GM}+75 \% \mathrm{~N})$ which was at par with $\mathrm{T} 5(\mathrm{GM}+100 \% \mathrm{~N})$ but highly significant over other treatments (Table 2). In case of number of spikelet spike- 
${ }^{1}$, statistically similar values were noted across $\mathrm{T} 3, \mathrm{~T} 4$ and T5. While higher value of seed index (45.90 and $45.93 \mathrm{~g}$ ), harvest index (0.50), biological yield (8.0 and $8.10 \mathrm{t} \mathrm{ha}^{-1}$ ) and grain yield (4.0 and $4.03 \mathrm{tha}^{-1}$ ) were found in $\mathrm{T} 4$ and T5 which were statistically at par from each other but highly significant over other treatments. These results are in line with the results of Palled et al. (2000) who recorded $11.7 \%$ yield increase in wheat when green manuring was practiced using Leucaena leucocephala (subabul) as green manure crop. Another group of researchers reported increase in grain yield of wheat when Leucaena leaf used as mulch and/or incorporated in the soil (Sharma et al., 2001). Our results are also supported by Prakash and Bhushan (2003) who used Leucaena leaf @ $3.14 \mathrm{t} \mathrm{ha}^{-1}$ as a green manured and planted wheat after 15 days with the application of $100 \%$ recommended $\mathrm{N}$ fertilizer which resulted in enhancement of wheat grain yield. In Table 3 , the lowest values of the investigated parameters were manifested in $\mathrm{T} 1$ where only green manuring was carried out (control plot) and $\mathrm{T} 2(\mathrm{GM}+25 \% \mathrm{~N})$. These results demonstrate that without integration of chemical fertilizer sole green manuring cannot be sufficient for getting a higher yield. It is supported by the findings of Dawe et al. (2003) and Thorup-Kristensen et al. (2012) that too much or solitary usage of green manuring can inflict negative influence on crop yield and the optimal rate of inorganic $\mathrm{N}$ by GM mainly depends on species of crop and soil fertility status (Yadav et al., 2000).

The average grain yield of wheat obtained in Pakistan is approximately $2.7 \mathrm{t} \mathrm{ha}^{-1}$ on the expense of recommended fertilizer and after the green manuring practice (T1) as well as the application of $25 \% \mathrm{~N}$ recommended fertilizer after green manuring (T2) produced grain yield of 2.12 and $2.20 \mathrm{t} \mathrm{ha}^{-1}$ which were lower than the average yield of Pakistan. Similar results have been observed in long term experiments conducted at various locations in South Asia indicating stagnation in yields with the passage of time even when recommended rate of fertilizer was used in wheat crop (Ladha et al., 2003). However, the application of 75 and $100 \%$ recommended $\mathrm{N}$ after green manuring enhanced wheat yield by 88 and $90 \%$ over control (no fertilizer application after green manuring). These results are in line with Shah et al. (2011) who evaluated six green manure crops in Pakistan and studied the subsequent influence on wheat crop where they noted $18.1 \%$ increase in grain yield. Sesbania performed better as compared to other legume crops used as green manure. Jal et al. (2014) reported grain yield enhancement from 1.9 to $5.5 \mathrm{t} \mathrm{ha}^{-1}$ when 0.0 to $240 \mathrm{~kg} \mathrm{~N} \mathrm{ha}^{-1}$ was applied to wheat crop

Table 2. Analysis of variance presenting F-value and coefficient of variance of the deliberate parameters of wheat crop and post soil organic matter and total nitrogen contents as affected by green manuring integrated with 25 , 50,75 and $100 \%$ recommended nitrogen.

\begin{tabular}{|c|c|c|}
\hline Particulars & F Value & $\mathrm{CV}$ \\
\hline \multicolumn{3}{|l|}{ Wheat crop characters } \\
\hline Plant height & $1.00^{\mathrm{NS}}$ & 0.05 \\
\hline Chlorophyll contents $\left(\mathrm{mg} \mathrm{g}^{-1}\right)$ & $2.66^{\mathrm{NS}}$ & 0.09 \\
\hline No. of tillers hill- ${ }^{-1}$ & $17.62^{* *}$ & 11.35 \\
\hline Spike length $(\mathrm{cm})$ & $17.49^{* *}$ & 5.18 \\
\hline No. of spikelet spike ${ }^{-1}$ & $25.00^{* * *}$ & 2.87 \\
\hline Seed index & $165.23^{* *}$ & 0.91 \\
\hline Harvest index & $4.23^{*}$ & 9.22 \\
\hline Biological yield $\left(\mathrm{t} \mathrm{ha}^{-1}\right)$ & $21.34^{* *}$ & 7.70 \\
\hline Grain yield $\left(\mathrm{t} \mathrm{ha}^{-1}\right)$ & $244.67^{* * *}$ & 3.31 \\
\hline \multicolumn{3}{|c|}{ Leaf tissue primary nutrient contents (\%) } \\
\hline Nitrogen $(\mathrm{N})$ & $125.17^{* *}$ & 2.88 \\
\hline Phosphorus (P) & $56.40^{* *}$ & 4.84 \\
\hline Potassium $(\mathrm{K})$ & $68.96^{* *}$ & 0.84 \\
\hline \multicolumn{3}{|c|}{ Grain tissue primary nutrient contents (\%) } \\
\hline $\mathrm{N}$ & $127.37^{* *}$ & 5.28 \\
\hline $\mathrm{P}$ & $56.64^{* *}$ & 4.78 \\
\hline $\mathrm{K}$ & $70.62^{* * *}$ & 1.47 \\
\hline \multicolumn{3}{|l|}{ Nutrient uptake (kg ha-1) } \\
\hline N uptake & $21.22^{* *}$ & 14.00 \\
\hline P uptake & $23.62^{* *}$ & 13.71 \\
\hline K uptake & $6.59^{*}$ & 13.48 \\
\hline
\end{tabular}




\begin{tabular}{|l|l|l|}
\hline Post soil OM and TN & & \\
\hline Soil organic matter (SOM) & $18.26^{* *}$ & 1.76 \\
\hline Total nitrogen (TN) & $20.83^{* *}$ & 1.41 \\
\hline
\end{tabular}

Leaf and grain tissue primary nutrient contents were highly significantly affected by green manuring and in conjunction with chemical fertilizer (Table 2 and 3). Among the treatments, T5 showed maximum leaf and grain tissue accumulation of $\mathrm{N}(3.35$ and $1.54 \%)$ and $\mathrm{P}$ $(0.75$ and $0.61 \%)$ while the lower values of $\mathrm{N}(2.11$ and $0.60 \%)$ and $\mathrm{P}(0.42$ and $0.35 \%)$ of both leaf and gain tissues were noted in control (GM). Statistically both T4 and $\mathrm{T} 5$ expressed at par differences for $\mathrm{N}$ and $\mathrm{P}$ contents in leaf and grain tissue. In case of $\mathrm{K}$ contents, both leaf and grain tissue showed non-significant variation across T3, T4 and T5 respectively. The enhancement in nutrient accumulation might be due to the improvement in soil properties as manifested in Table 2 that green manuring increased soil organic matter and caused slight reduction in $\mathrm{pH}$. The availability of phosphorus in calcareous soil is limited and is one of the main constraints in yield enhancement. Green manuring has resulted in improvement in its availability which is reflected in higher leaf and grain tissue $\mathrm{P}$ accumulation. Similar results were reported by Belachew and Abera (2011) who observed reduction in soil $\mathrm{pH}$ along with enhancement of SOC noted after three weeks of vetch green manuring over fallo

Table 3. Effect of green manuring integrated with recommended $\mathrm{N}$ on growth, yield and nutrient accumulation of wheat

\begin{tabular}{|c|c|c|c|c|c|c|c|}
\hline \multirow[t]{2}{*}{ Particulars } & \multicolumn{5}{|c|}{ Treatments } & \multirow{2}{*}{$\begin{array}{c}\text { LSD } \\
(\mathbf{p}<0.05)\end{array}$} & \multirow[t]{2}{*}{ S.E. } \\
\hline & $\begin{array}{c}\text { T1 } \\
(\mathbf{G M})\end{array}$ & $\begin{array}{c}\text { T2 } \\
(\mathrm{GM}+ \\
25 \% \mathrm{~N})\end{array}$ & $\begin{array}{c}\text { T3 } \\
(\text { GM+ } \\
\text { 50\%N) } \\
\end{array}$ & $\begin{array}{c}\text { T4 } \\
(\mathrm{GM}+ \\
75 \% \mathrm{~N})\end{array}$ & $\begin{array}{c}\text { T5 } \\
(\mathrm{GM}+ \\
100 \% \mathrm{~N})\end{array}$ & & \\
\hline \multicolumn{8}{|l|}{ Wheat crop characters } \\
\hline Plant height $(\mathrm{cm})$ & $97.17 \mathrm{a}$ & $97.20 \mathrm{a}$ & $97.20 \mathrm{a}$ & $97.23 \mathrm{a}$ & $97.23 \mathrm{a}$ & 0.091 & 0.039 \\
\hline $\begin{array}{l}\text { Chlorophyll contents } \\
\left(\mathrm{mg} \mathrm{g}^{-1}\right)\end{array}$ & $34.07 \mathrm{~b}$ & $34.11 \mathrm{ab}$ & $34.12 \mathrm{ab}$ & $34.13 \mathrm{a}$ & $34.13 \mathrm{a}$ & 0.055 & 0.024 \\
\hline No. of tillers hill- ${ }^{-1}$ & $6.0 \mathrm{c}$ & $6.0 \mathrm{c}$ & $8.0 \mathrm{~b}$ & $10.67 \mathrm{a}$ & $10.33 \mathrm{a}$ & 1.753 & 0.760 \\
\hline Spike length $(\mathrm{cm})$ & $7.0 \mathrm{c}$ & $7.07 \mathrm{c}$ & $8.13 \mathrm{~b}$ & $9.20 \mathrm{a}$ & $8.87 \mathrm{a}$ & 0.786 & 0.341 \\
\hline No. of spikelet spike ${ }^{-1}$ & $10.0 \mathrm{~b}$ & $10.0 \mathrm{~b}$ & $11.67 \mathrm{a}$ & $11.67 \mathrm{a}$ & $11.67 \mathrm{a}$ & 0.595 & 0.258 \\
\hline Seed index & $39.10 \mathrm{~d}$ & $41.80 \mathrm{c}$ & $44.33 \mathrm{~b}$ & $45.90 \mathrm{a}$ & $45.93 \mathrm{a}$ & 0.746 & 0.323 \\
\hline Harvest index & $0.40 \mathrm{~b}$ & $0.41 \mathrm{~b}$ & $0.43 \mathrm{ab}$ & $0.50 \mathrm{a}$ & $0.50 \mathrm{a}$ & 0.078 & 0.034 \\
\hline Biological yield $\left(\mathrm{t} \mathrm{ha}^{-1}\right)$ & $5.27 \mathrm{c}$ & $5.33 \mathrm{c}$ & $7.10 \mathrm{~b}$ & $8.0 \mathrm{ab}$ & $8.10 \mathrm{a}$ & 0.981 & 0.425 \\
\hline Grain yield $\left(\mathrm{t} \mathrm{ha}^{-1}\right)$ & $2.12 \mathrm{c}$ & $2.20 \mathrm{c}$ & $3.10 \mathrm{~b}$ & $4.0 \mathrm{a}$ & $4.03 \mathrm{a}$ & 0.193 & 0.084 \\
\hline \multicolumn{8}{|c|}{ Leaf tissue primary nutrient contents (\%) } \\
\hline Nitrogen $(\mathrm{N})$ & $2.11 \mathrm{~d}$ & $2.53 \mathrm{c}$ & $3.11 \mathrm{~b}$ & $3.28 \mathrm{a}$ & $3.35 \mathrm{a}$ & 0.156 & 0.068 \\
\hline Phosphorus (P) & $0.42 \mathrm{~d}$ & $0.51 \mathrm{c}$ & $0.61 \mathrm{~b}$ & $0.62 \mathrm{~b}$ & $0.75 \mathrm{a}$ & 0.053 & 0.023 \\
\hline Potassium $(\mathrm{K})$ & $2.98 \mathrm{c}$ & $3.13 \mathrm{~b}$ & $3.24 \mathrm{a}$ & $3.28 \mathrm{a}$ & $3.28 \mathrm{a}$ & 0.050 & 0.022 \\
\hline \multicolumn{8}{|c|}{ Grain tissue primary nutrient contents (\%) } \\
\hline $\mathrm{N}$ & $0.60 \mathrm{~d}$ & $0.92 \mathrm{c}$ & $1.36 \mathrm{~b}$ & $1.48 \mathrm{a}$ & $1.54 \mathrm{a}$ & 0.117 & 0.051 \\
\hline $\mathrm{P}$ & $0.35 \mathrm{~d}$ & $0.42 \mathrm{c}$ & $0.50 \mathrm{~b}$ & $0.51 \mathrm{~b}$ & $0.61 \mathrm{a}$ & 0.043 & 0.019 \\
\hline $\mathrm{K}$ & $1.19 \mathrm{c}$ & $1.30 \mathrm{~b}$ & $1.38 \mathrm{a}$ & $1.14 \mathrm{a}$ & $1.41 \mathrm{a}$ & 0.037 & 0.016 \\
\hline
\end{tabular}

Mean bearing the same letters are statistically being alike

Nutrient uptake and use efficiency are important for plant growth and yield. In this study, the effect of green manuring on subsequent planting of wheat revealed highly significant variations for nutrient uptake, and $\mathrm{N}$ use efficiency as given in Figure 1a,b,c.\&d. Among the treatments, maximum $\mathrm{N}$ uptake $\left(200.34 \mathrm{~kg} \mathrm{ha}^{-1}\right)$ was observed in T5 immediately followed by $193.0 \mathrm{~kg} \mathrm{~N}^{-1}$ in T4 and minimum $\mathrm{N}$ uptake (79.38 $\left.\mathrm{kg} \mathrm{ha}^{-1}\right)$ was found in control treatment (Figure 1a). Statistically N uptake across $\mathrm{T} 3, \mathrm{~T} 4$ and $\mathrm{T} 5$ was at par from each other but highly significant over $\mathrm{T} 1$ and $\mathrm{T} 2$ respectively. Similar results were also reported by Jat et al. (2014) who found N uptake of 41.2 to $217.7 \mathrm{~kg} \mathrm{ha}^{-1}$ when $\mathrm{N}$ fertilizer was applied from 0.0 to $240 \mathrm{~kg} \mathrm{ha}^{-1}$. In case of $\mathrm{P}$ uptake, after green manuring the application of $100 \%$ recommended $\mathrm{N}$ to wheat crop showed higher P uptake of $55.67 \mathrm{~kg} \mathrm{ha}^{-1}$ followed by $45.70 \mathrm{~kg} \mathrm{ha}^{-1}$ in T4 (Figure 1b) where both T4 and T5 were statistically at par from one another. Similarly, like N uptake, K uptake was also statistically non-significant across T3, T4 and T5 as shown in Figure 
1c. After completion of production cycle of wheat crop, the soil analysis for soil organic matter (SOM) and total nitrogen (TN) revealed maximum but non-significant SOM $(0.90,0.91$ and $0.93 \%)$ across T3, T4 and T5 (Figure 2a) while $\mathrm{TN}$ was at par across all treatments (Figure 2b). Nitrogen use efficiency of wheat was higher (146\%) in plot where after green manuring $50 \%$ recommended $\mathrm{N}$ was applied followed by $126.145 \%$ in $\mathrm{T} 4(\mathrm{GM}+75 \% \mathrm{~N})$ (Figure1d). According to Pathak et al. (2003) that in South Asia wheat crop is cultivated in soil having low organic matter where the applied fertilizer bearing grade of 120 50-60 kg NPK ha-1 manifested 58, 27 and 51\% recovery efficiency on average basis. Our results demonstrate that augmentation in nutrient uptake and $\mathrm{N}$ use efficiency is due to improvement in soil organic matter and soil total nitrogen after completion of production of wheat which is reflected in Figure $2 a \& b$ that further evidenced from the linear regression among soil $\mathrm{TN}, \mathrm{N}$ uptake and $\mathrm{P}$ uptake and SOM (Figure 3a, b \& c). It was noted that under the influence of green manuring in conjunction with chemical fertilizer soil TN, N and P uptake of wheat crop was positively and highly significantly correlated with SOM having coefficient of determination of 63,73 and $76 \%$ with coefficient of variance $(r)$ of $0.79,0.85$ and 0.87 respectively (Figure $3 \mathrm{a}, \mathrm{b} \& \mathrm{c}$ ). Among the soil fertility indexes, soil organic carbon is the most important one that driven all soil physical, chemical and biological processes responsible for soil health and productivity (Bedini et al., 2013; Tian et al., 2016). According to Yao et al. (2017) that soil organic carbon increased from 14 to $24 \%$ by green manuring over fallow land and other group of researchers narrated that green manuring augmented carbon sequestration (McDaniel et al., 2014). Our results are also in line with findings of Benbi et al. (2012) who observed augmentation in SOM and TN when after green manuring recommended $\mathrm{N}$ fertilizer was applied. The reason behind nutrient availability and uptake by crops after green manuring is due to the development of soil structure and mineralization of organic substances (Mohanty et al., 2013; Kumar et al., 2014).
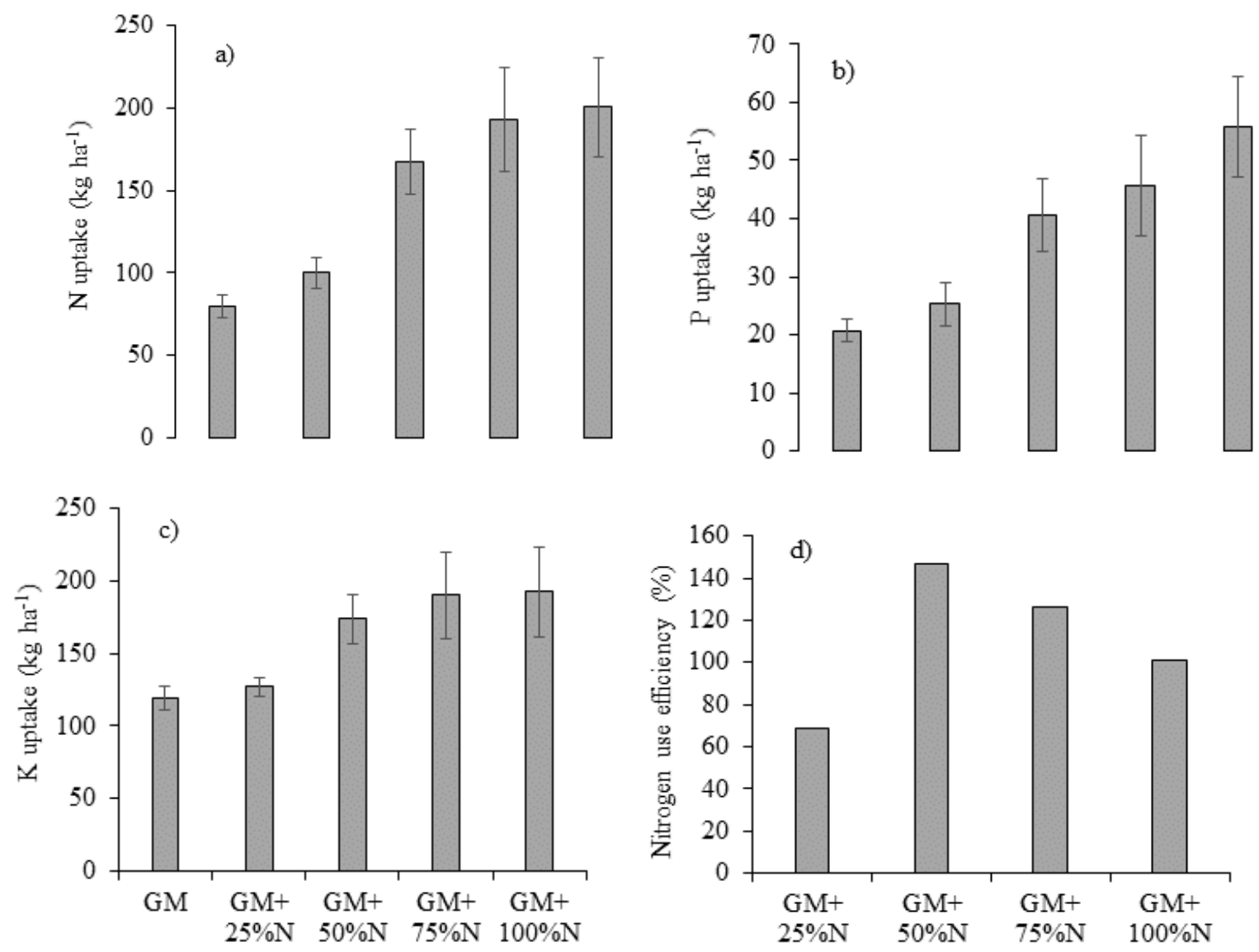

Figure 1. Green manuring integrated with 25, 50,75 and $100 \%$ recommended $\mathrm{N}$ influenced $\mathrm{N}$ uptake (a), P uptake (b), K uptake (c) and nitrogen use efficiency (d) of wheat. Error bar represents standard error of means. 

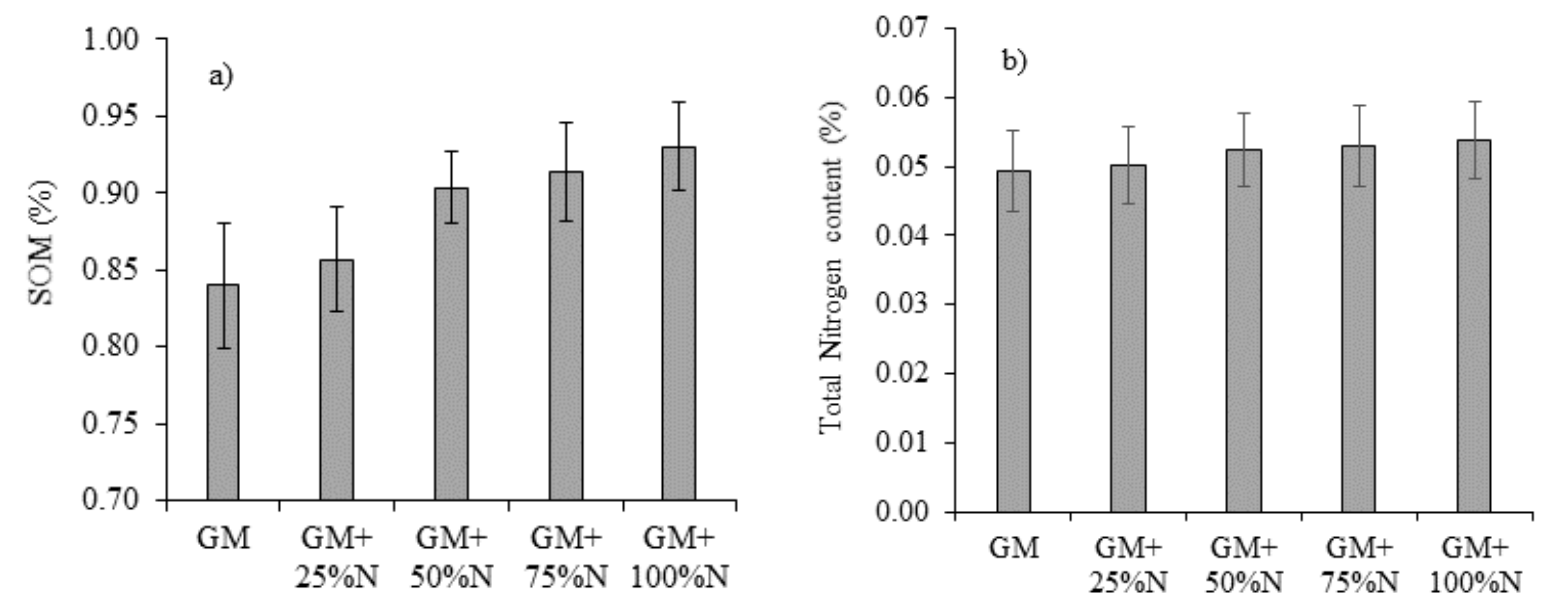

Figure 2. Soil organic matter (a) and total nitrogen content (b) were influenced by green manuring integrated with 25 , 50,75 and $100 \%$ recommended N. Error bar represents standard error of means.
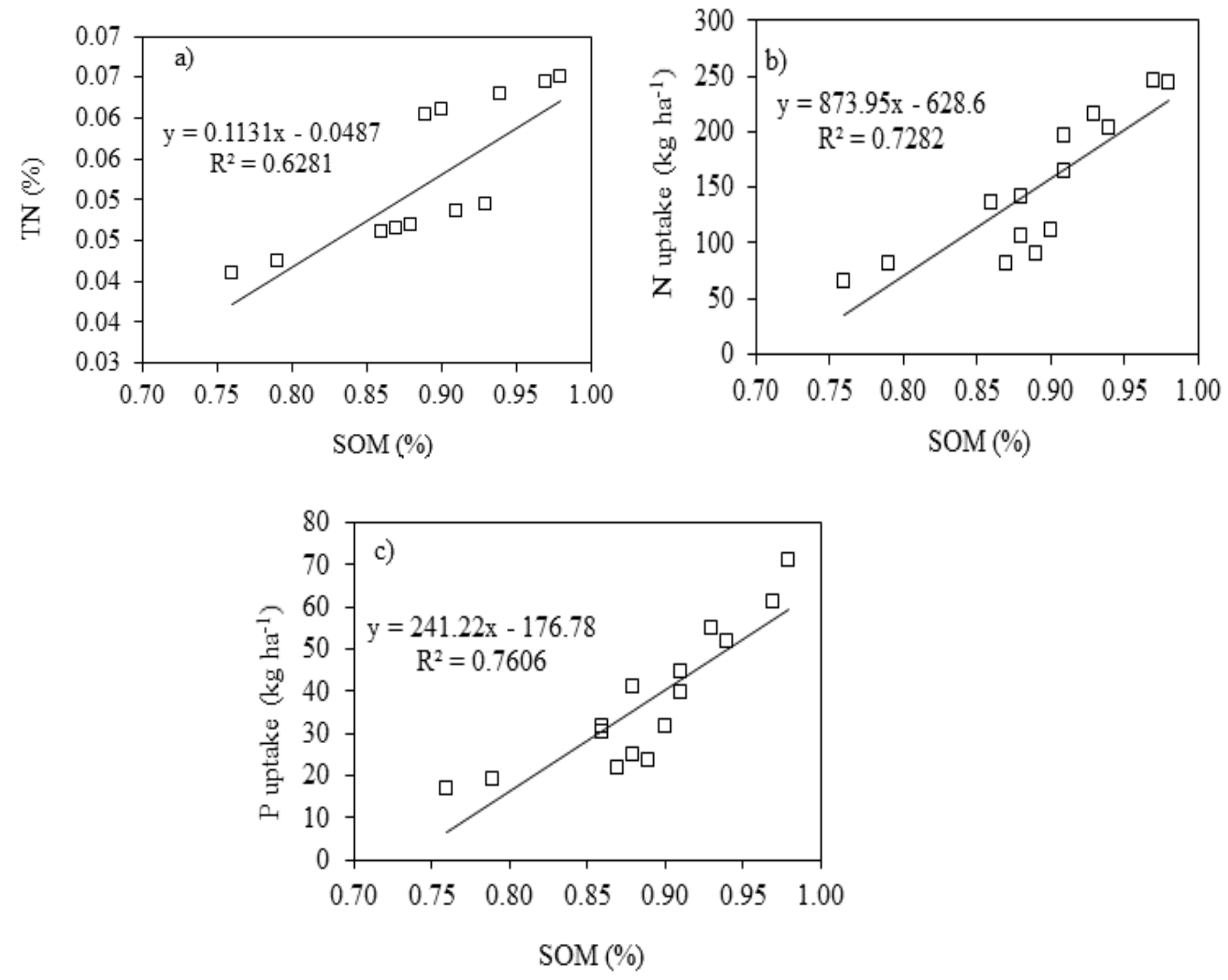

Figure 3. Soil organic matter was significantly and positively correlated with soil total nitrogen (a), N uptake (b) and $\mathrm{P}$ uptake (c) under the influence of green manuring integrated with 25, 50,75 and 100\% recommended $\mathrm{N}$ of wheat as succeeding crop 


\section{Conclusion}

This present study reported that the green manuring enhanced soil organic matter and soil total nitrogen that helped in better succeeding crop establishment when 75 and $100 \%$ recommended $\mathrm{N}$ was applied. While, sole green manuring cannot ensure sustainable crop production reflecting lower grain yield and nutrient uptake of wheat. Higher $\mathrm{N}$ use efficiency was found in treatment where after green manuring 50 and $75 \%$ recommended $\mathrm{N}$ fertilizer was applied. Greater grain yield of wheat was obtained in the plot where after green manuring 75 and $100 \%$ recommended $\mathrm{N}$ was applied. Consequently, it is suggested that various green manure crops can be evaluated to augment SOM and TN for enhancing the growth and yield of the succeeding crop with the integration of $75 \% \mathrm{~N}$ fertilizer.

\section{References}

Bai Y, Yan, Y., Zuo, W., Gu, C., Xue, W., Mei, L., Shan, Y., \& Feng, K. (2017). Coastal mudflat saline soil amendment by dairy manure and green manuring. Inter J Agron. 1-9.

Bedada, W., Karltun, E., Lemenih, M., \& Tolera, M. (2014). Long-term addition of compost and NP fertilizer increases crop yield and improves soil quality in experiments on smallholder farms. Agric. Ecosyst. Environ. 195: 193-201.

Bedini, S., Avio, L., Sbrana, C., Turrini, A., Migliorini, P., Vazzana, C., Giovannetti, M. (2013). Mycorrhizal activity and diversity in a long-term organic Mediterranean agroecosystem. Boil. Fertil. Soils, 49:781-790.

Belachew, T., \& Abera, Y. (2011). Effect of green manuring in combination with nitrogen on soil fertility and yield of bread wheat (Triticum aestivum) under double cropping system of Sinanadinsho, Southeast Ethiopia. JBES 1: 1-11.

Benbi, D.K., Toor, A.S., \& Kumar, S. (2012). Management of organic amendments in rice-wheat cropping system determines the pool where carbon is sequestered. Plant Soil, 360:145-162.

Black, C.A. (1993). Soil fertility evaluation and control. Lewis publishers, Boca Raton, Florida, USA.

Bohlool, B.B., Ladha, J.K., Grrity, D.P. \& George, T. (2004). Biological nitrogen fixation for sustainable agriculture: a perspective. Plant Soil 141: 1-11.

Bouyoucos, G.J. (1962). Hydrometer method improved for making particle-size analysis of soils. Agron. J., 53:464-465.

Cao, Y., Tian, Y., Yin, B., \& Zhu, Z. (2013). Assessment of ammonia volatilization from paddy fields under crop management practices aimed to increase grain yield and N efficiency. Field Crops Research, 147: 23-31. DOI 10.1016/j.fcr.2013.03.015.
Carlsson, G., \& Huss-Danell, K. (2003). Nitrogen fixation in perennial forage legumes in the field. Plant Soil 253: 353- 372 .

Cottenie, A. (1980). Soil and Plant testing as a basis of fertilizer recommendations. FAO soil Bulletin 38/2. Differences de techniques. Fruits, 32:151-166.

Dawe, D., Dobermann, A., Ladha, J.R., Yadav, L., Bao, Gupta, R., Lal, P., Panaullah, G., Sariam, O. \& Singh, Y. et al. (2003). Do organic amendments improve yield trends and profitability in intensive rice systems? Field Crop. Res. 83:191-213.

Deng, F., Wang, L., Ren, W.J., \& Mei, X.F. (2014). Enhancing nitrogen utilization and soil nitrogen balance in paddy fields by optimizing nitrogen management and using polyaspartic acid urea. Field Crops Research, 169, 30-38. DOI 10.1016/j.fcr.2014.08.015.

Dikemann, K.H., De Datta, S.K., Ottow, J.C.G. (1993). Nitrogen uptake and recovery from urea and green manure in lowland rice measured by $15 \mathrm{~N}$ and nonisotope techniques. Plant Soil 148: 91-99.

Ghuman, B.S., Sur, H.S. (2006). Effect of manuring on soil properties and yield of rainfed wheat. J Indian Soc Soil Sci 54: 6-11.

Hasan, Z.A., Khan, A., Jha, A.K., Razzaq, A., Sajjad, M.R., \& Muhammad, G. (2014). Green manuring for improved wheat yield through moisture conservation in rainfed areas of Pakistan. J Agri Food Appl Sci 2(6): 171-17

Jat, M.L., Bijay-Singh, \& Gerard, B. (2014). Nutrient Management and Use Efficiency in Wheat Systems of South Asia. Advances in Agronomy, 171259. doi:10.1016/b978-0-12-800137-0.00005-4

Jones, J.B. (1991). Kjeldahl method for nitrogen determination. Micro-Macro Publishing Inc., Athens, GA, USA.

Knudsen, D., Peterson, G.A., \& G.A. Pratt, G.A. (1982). Lithium, sodium and potassium. P. 225-245. In: A.L page (Ed.), Methods of Soil Analysis, Part 2: Chemical and microbiological properties. Am. Soc. Agron, Madison WI, USA.

Kumar, N., Mina, B.L., \& Chandra, S. (2011). In-situ green manuring for enhancing productivity, profitability and sustainability of upland rice. Nutr Cycl Agroecosys 90: 369-377.

Kumar, S., Patra, A.K., Singh, D., Purakayastha, T.J. (2014). Long-Term Chemical Fertilization Along with Farmyard Manure Enhances Resistance and Resilience of Soil Microbial Activity against Heat Stress. J. Agron. Crop Sci., 200: 156-162.

Ladha, J.K., Dawe, D., Pathak, H., Padre, A.T., Yadav, R.L., Yadvinder-Singh, Bijay-Singh, Singh Y., Singh, P., Kundu, A.L., Sakal, R., Ram, N., Regmi, A.P., Gami, S.K., Gupa, R.K., \& Hobbs, P.R. (2003). How extensive are yield declines in long-term rice- 
wheat experiments in Asia? Field Crop Res. 81: 159181.

Liu, D., Ishikawa, H., Nishida, V., Tsuchiya, K., Takahashi, T. et al. (2015). Effect of paddy-upland rotation on methanogenic archaeal community structure in paddy field soil. Microbial Ecology, 69(1):160-168. DOI 10.1007/ s00248-014-0477-3.

Luo, Y., A. Iqbal, L. He, Q. Zhao, S. Wei, et al. (2020). Long-term no-tillage and straw retention management enhances soil bacterial community diversity and soil properties in Southern China. Agronomy, 10(9), $1233 . \quad$ DOI 10.3390/agronomy 10091233.

Ma, F., Ma, H.L., Qiu, H., \& Yang, H.Y. (2015). Effects of water levels and the additions of different nitrogen forms on soil net nitrogen transformation rate and $\mathrm{N}_{2} \mathrm{O}$ emission in subtropical forest soils. Yingyong Shengtai Xuebao, 26(2):379-387.

McDaniel, M.D., Tiemann, L.K., \& Grandy, A.S. (2014). Does agricultural crop diversity enhance soil microbial biomass and organic matter dynamics? A meta-analysis. Ecol. Appl. 24: 560-570.

McLean, E.O. (1982). Soil pH and lime requirement In: Page, A.L. (Ed.), Methods of soil analysis, Part 2: chemical and microbiological properties .AM. Soc. Agron., Madison, WI, USA., P. 199-224.

Mohanty, S., Nayak, A., Kumar, A., Tripathi, R., Shahid, M., Bhattacharyya, P., Raja, R., Panda, B., \& Shahid, D.M. (2013). Carbon and nitrogen mineralization kinetics in soil of rice-rice system under long term application of chemical fertilizers and farmyard manure. Eur. J. Soil Boil., 58:113-121.

Palled, Y.B., Desai, B.K., \& Prabhakar, A.S. (2000). Integrated nutrient in alley cropped maize ( $\mathrm{Zea}$ mays)-groundnut (Arachis hypogaea) system with subabul (Leucaena leucocephala). Indian J. Agron. 45: 520-555.

Pathak, H., Aggarwal, P.K., Roetter, R., Kalra, N.S., Bandyopadhaya, K., Prasad, S., \& van Keulen, H. (2003). Modelling the quantitative evaluation of soil nutrient supply, nutrient use efficiency, and fertilizer requirements of wheat in India. Nutr. Cycl. Agroecosyst. 65:105-113.

Patra, D.D., Anwar, A., \& Chand, S. (2000). Integrated nutrient management and waste recycling for restoring soil fertility and productivity in Japanese mint and mustard sequence in Uttar Pradesh. Indin Agr Ecosys Environ 80: 267-275.

Prakash, O.M., \& Bhushan, L.S. (2003). Effect of fertilizer substitution through white lead tree (Leucaena leucocephala) green biomass on growth, yield and economics of wheat (Triticum aestivum) crop in degraded lands. Indian J. Agric. Sci. 73: 311314.

Ramos, M.G., Villatoro, M.A.A., Urquiaga, S., Alves, B.J., \& Boddey, R.M. (2001). Quantification of the contribution of biological nitrogen fixation to tropical green manure crops and the residual benefit to a subsequent maize crop using $15 \mathrm{~N}$-isotope techniques. J Biotechnol 91(2-3): 105-115.

Salahin, N., Alam, M.K., Islam, M.M., Naher, L., \& Majid, N.M. (2013). Effects of green manure crops and tillage practice on maize and rice yields and soil properties. Aust J Crop Sci 7: 1901.

Shah, Z., Ahmed, S.R., Rahman, H., \& Shah, M.Z. (2011). Sustaining rice-wheat system through management of legumes. II. Effect of green manure legumes and $\mathrm{N}$ fertilizer on wheat yield. Pak. J. Bot. 43: 2093-2097.

Singh, S., Singh, R.J., Kumar, K., Singh, B., \& Shukla, L. (2013). Biofertilizers and Green manuring for sustainable agriculture, 1 st edn. New India Publishing Agency, New Delhi, 129- 150.

Sonneveld, C., \& Van Dijk, P.A. (1982). The effectiveness of some washing procedures on the removal of contaminates from plant tissues of glass house crops. Communications in Soil Science and Plant analysis 13: 487-496.

Sultan pour, P.N., Schwab, A.P. (Eds.). (1977). A new soil test for simultaneous extraction of macro-micro nutrients in alkaline soils. Commun. soil sci., plant Anal., 8:195-207.

Sultani, M.I., Shaukat, M., Mahmood, I.A., \& Joyia, M.F. 2004. Wheat growth and yield response to various green manure legumes and different $\mathrm{P}$ levels in Pothowar region. Pak. J. Agri. Sci., 41(3-4):102-108.

Thorup-Kristensen, K., Dresbøll, D.B., \& Kristensen, H.L. (2012). Crop yield, root growth, and nutrient dynamics in a conventional and three organic cropping systems with different levels of external inputs and $\mathrm{N}$ re-cycling through fertility building crops. Eur. J. Agron., 37: 66-82.

Tian, S., Ning, T., Wang, Y., Liu, Z., Li, G., Li, Z., \& Lal, R. (2016). Crop yield and soil carbon responses to tillage method changes in North China. Soil Tillage Res. 163: 207-213.

Walkley, A. (1947). A critical examination of rapid method for exterminating organic carbon in soil: Effect of variations in digestion conditions and of organic soil constituents. Soil Sci 63:251-263.

Wolf, B. (1982). A comprehensive system of leaf analysis and its use for diagnosing crop nutrient status. Communications in Soil Science and Plant Analysis 13: $1035-1059$.

Yadav, R.I. (2001). On farm experiments on integrated nutrient management in rice-wheat cropping systems. Exp Agr 7: 99-113.

Yadav, R.L., Singh, V.K., Dwivedi, B.S., \& Shukla, A.K. (2003). Wheat productivity and $\mathrm{N}$ use-efficiency as influenced by inclusion of cowpea as a grain legume in a rice-wheat system. J Agri Sci 141: 213- 220.

Yadav, R., Dwivedi, B., Prasad, K., Tomar, O., Shurpali, N., Pandey, P., \& Shurpali, N. (2000). Yield trends, 
and changes in soil organic-C and available NPK in a long-term rice-wheat system under integrated use of manures and fertilisers. Field Crop. Res., 68:219-246.

Yao, Z., Zhang, D., Yao, P., Zhao, N., Liu, N., Zhai, B., Zhang, S., \& Li, Y. (2017). Science of the Total Environment Coupling life-cycle assessment and the RothC model to estimate the carbon footprint of green manure-based wheat production in China. Sci. Total Environ. 607-608: 433-442.
Zhang, Y., Chen, X.P., Ma, W.Q., \& Cui, Z.L. (2017). Elucidating variations in nitrogen requirement according to yield, variety and cropping system for Chinese rice production. Pedosphere, 27(2):358-363

Zhou, C.H., Zhao, Z.K., Pan, X.H., Huang, S., Tan, X.M. et al. (2016). Integration of growing milk vetch in winter and reducing nitrogen fertilizer application can improve rice yield in double-rice cropping system. Rice Science, 23(3): 132-143

Publisher's note: JOARPS remains neutral with regard to jurisdictional claims in published maps and institutional affiliations.

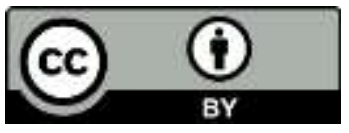

This is an open access article distributed under the terms of the Creative Commons Attribution License (CC BY 4.0), which permits unrestricted use, distribution, and reproduction in any medium, provided the original author and source are credited. To view a copy of this license, visit http://creativecommons.org/licenses/by/4.0/. 